\title{
Calcitonin gene related peptide inhibits basal, pentagastrin, histamine, and bethanecol stimulated gastric acid secretion
}

\author{
H J LENZ, M T MORTRUD, J E RIVIER, AND M R BROWN \\ From the Division of Gastroenterology, Department of Medicine, UCSD Medical Center, San Diego, \\ California, and the Peptide Biology Laboratory, The Salk Institute, La Jolla, California, USA
}

SUMmaRY This study was designed to examine the effect of calcitonin gene related peptide on gastric acid secretion in the rat. Calcitonin gene related peptide $(1 \mathrm{pmol}-1 \mathrm{nmol} / \mathrm{rat})$ injected intravenously inhibited basal gastric acid secretion in awake, freely moving rats. Calcitonin gene related peptide decreased gastric secretion stimulated by histamine, pentagastrin, or bethanecol in anaesthetised rats. The inhibitory effect was immediate and most pronounced in the first hour and diminished during the second hour. The $\mathrm{N}$ - and $\mathrm{C}$-terminal fragments of calcitonin gene related peptide, CGRP ${ }^{1-14}$ and $\left[\mathrm{Tyr}^{23}\right] \mathrm{CGRP}^{23-37}$, did not affect gastric acid secretion. [acetamidomethyl-cys ${ }^{2,7}$ ]CGRP, the linear cysteine-protected molecule devoid of the disulphide bridge, was not biologically active. After truncal vagotomy or atropine sulphate, calcitonin gene related peptide did not inhibit gastric secretion. These studies indicate that calcitonin gene related peptide administered peripherally inhibits basal and stimulated gastric acid secretion in the rat. Both $\mathrm{C}$ - and $\mathrm{N}$-terminal residues as well as the disulphide bridge are necessary for the inhibitory effect on gastric secretion. Inhibition of gastric acid secretion by calcitonin gene related peptide may depend on intact vagal cholinergic fibres.

Calcitonin gene related peptide is a 37 -residue peptide with an N-terminal 6-membered disulphide ring. ${ }^{1}$ In contrast with the traditional approach of peptide characterisation that is based upon sequence analysis, the amino acid sequence of calcitonin gene related peptide was predicted by the mRNA derived from alternative splicing of RNA transcripts of the calcitonin gene. ${ }^{1}$ The predicted peptide has been identified immunohistochemically in the central and peripheral nervous systems as well as the gastrointestinal tract. ${ }^{2}$ Furthermore, calcitonin gene related peptide-like immunoreactivity was found throughout the gut and most abundantly in the stomach and duodenum of the rat (personal communication). Calcitonin gene related peptide injected intracerebroventricularly stimulated noradrenergic sympathetic outflow and increased mean arterial pressure and heart rate. ${ }^{3}$ Peripheral administration of this peptide decreased mean arterial pressure. ${ }^{3}$ The purpose of this study was to

Address for correspondence: Dr M R Brown, The Salk Institute, Peptide Biology Laboratory, PO Box 85800, San Diego 92138, USA.

Received for publication 9 July 1984 evaluate the effect of calcitonin gene related peptide on basal and stimulated gastric acid secretion and to delineate its structure activity relationship as well as possible mechanisms of its action.

\section{Methods}

\section{ANIMALS}

Male Sprague-Dawley rats $(200-250 \mathrm{~g})$ were used in all experiments. The animals were housed under temperature, humidity, and illumination (from 0700 to 1900) controlled conditions and maintained on Purina Laboratory Chow and water ad libitum. Two days before the experiments, the animals were fitted with chronic intravenous jugular vein catheters. Silastic tubing, $2 \mathrm{~cm}$ in length, connected to polyethylene tubing (PE-50) was inserted into the right jugular vein. The intravenous catheter was routed subcutaneously to exit at the back of the neck, fitted with stainless steel intravenous connector tubing (Small Parts, Inc, Miami, Fl), and sewed onto the skin. The studies were performed in 24 hour fasted rats with free access to water until the beginning of 
the experiment.

Under light ether anaesthesia, freshly dissolved peptide or the vehicle, $0.15 \mathrm{M} \mathrm{NaCl}$, was injected intravenously in a volume of $0.2 \mathrm{ml}$. After a midline abdominal incision, the pylorus was ligated and the abdominal wall closed in layers. ${ }^{4}$ The animals were awake within five minutes after pylorus ligation and freely moving in single cages. Two hours later, the animals were decapitated, the stomach excised, and the gastric content centrifuged. The volume of the supernatant was recorded and the hydrogen ion concentration determined in vitro to $\mathrm{pH} 7.0$ using an automatic titrator (Radiometer, Copenhagen). ${ }^{5}$

To determine the effect of calcitonin gene related peptide on stimulated gastric acid secretion, and in vagotomised or atropinised rats, animals were fitted with jugular venous catheters as described above. Two days later, under urethane anaesthesia (1.25 $\mathrm{mg} / \mathrm{kg}$ intraperitoneally), double lumen plastic cannulae were implanted into the forestomach and the pylorus ligated. ${ }^{6}$ To prevent gastric contamination with saliva, a polyethylene tube (PE-200) was inserted into the trachea and the oesophagus ligated above the thoracic cavity. Avoiding gastric distension, the stomach was carefully flushed with 10 $\mathrm{ml}$ of $0.15 \mathrm{M} \mathrm{NaCl}$ every 10 minutes and the effluent titrated to $\mathrm{pH} 7.0$ in vitro with $0.1 \mathrm{~N} \mathrm{NaOH}$ on an automatic titrator. ${ }^{5}$ After one hour of basal collections, calcitonin gene related peptide $(2 \cdot 2$ $\mathrm{nmol})$ or $\mathrm{NaCl}(0 \cdot 15 \mathrm{M})$ were intravenously administered as a bolus injection $(0.2 \mathrm{ml})$. Pentagastrin (16 $\mu \mathrm{g} / \mathrm{kg} / \mathrm{h}$; Peptavlon, Ayerst, New York, NY), histamine-diHCl ( $4 \mathrm{mg} / \mathrm{kg} / \mathrm{h}$; Sigma Chemical Co, St Louis, MO), or bethanecol $(4 \mathrm{mg} / \mathrm{kg} / \mathrm{h}$; Sigma Chemical Co, St Louis, MO), a cholinergic agonist, were intravenously infused for two hours.

In some experiments subdiaphragmatic bilateral truncal vagotomy was performed. Both vagal nerve trunks were isolated, pulled downward into the abdomen and at least a $1 \mathrm{~cm}$ segment was excised. ${ }^{7}$ To divide any intramural fibres, a seromuscular myotomy of the lower oesophagus was performed. In other experiments, animals were pretreated 30 minutes before peptide injection with atropine sulphate $(1 \mathrm{mg} / \mathrm{kg}$ subcutaneously; Sigma Chemical Co, St Lousi, MO).

Rat calcitonin gene related peptide was synthesised using solid phase methodology as described previously. ${ }^{8}$ The peptide was greater than $95 \%$ pure as determined by amino acid analysis and analytic HPLC.

After analysis of variance, differences between treatment groups were determined by the multiple range tests of Dunnett and Duncan. Results are expressed as the mean $\pm 1 \mathrm{SE}$ and considered significant if $\mathrm{p}<0 \cdot 05$.

\section{Results}

Calcitonin gene related peptide dose-dependently inhibited basal gastric acid secretion in awake, freely moving rats (Fig. 1). One $\mathrm{nmol} / \mathrm{calcitonin}$ gene related peptide decreased the two hour total acid output by $72 \%$. The lowest peptide dose, 1 pmol, still inhibited acid output by $40 \%(\mathrm{p}<0 \cdot 01)$. The half-maximal effective dose was $10 \mathrm{pmol}$ per animal or $44 \mathrm{pmol} / \mathrm{kg}$. Calcitonin gene related peptide $(2 \cdot 2$ $\mathrm{nmol}$ ) decreased both the mean $\pm \mathrm{SE}$ volume from $4 \cdot 1 \pm 0 \cdot 3$ to $1 \cdot 4 \pm 0.4 \mathrm{ml} / 2 \mathrm{~h}$ and the hydrogen ion concentration from $107 \pm 8$ to $39 \pm 10 \mathrm{mM}(\mathrm{n}=6$; $\mathrm{p}<0.01)$.

Neither the N-terminal fragment, CGRP ${ }^{1-14}$, nor the C-terminal residue, $\left[\mathrm{Tyr}^{23}\right]{ }^{2} \mathrm{CGRP}^{23-37}$, were biologically active (Fig. 2). Also, the linear, cysteine protected molecule [acetamindomethylcys $\left.^{2,7}\right]$ CGRP ([ACM-cys $\left.{ }^{2,7}\right]$ CGRP) did not inhibit acid secretion (Fig. 2).

Calcitonin gene related peptide inhibited pentagastrin stimulated gastric acid secretion from the 20 min to the $110 \mathrm{~min}$ period in anaesthetised rats (Fig. 3 , upper panel). Similarly, calcitonin gene related peptide inhibited gastric secretion in response to histamine (Fig. 3, middle panel) and the cholinergic agent bethanecol (Fig. 3, lower panel). The inhibitory effect of calcitonin gene related peptide was most pronounced during the first 60 minutes and steadily ceased towards the end of the study (Fig. 4).

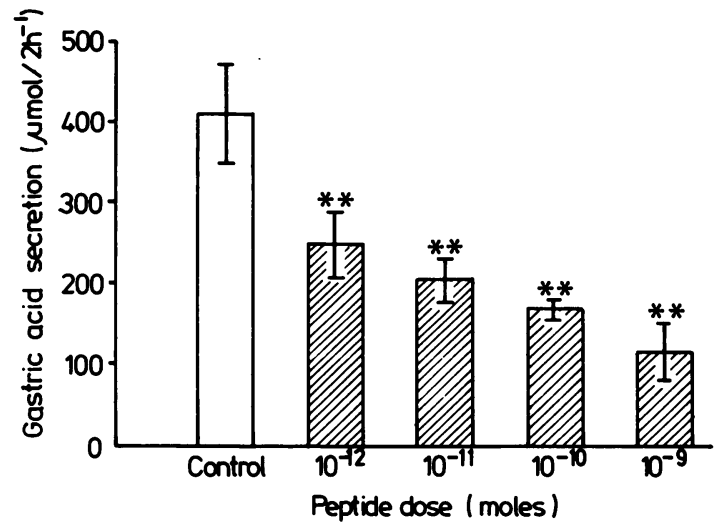

Fig. 1 Effect of various doses of calcitonin gene related peptide on basal gastric acid secretion (mean $\pm S E$ ) in awake freely moving rats. Calcitonin gene related peptide or control were injected intravenously as a bolus before pylorus ligation. Two hours later the animals were decapitated and gastric acid secretion determined. ${ }^{* *}$, $p<0.01$ compared with control $(n=5)$. A dose of $10^{-13}$ moles did not significantly decrease the two hour total acid output (data not shown). 


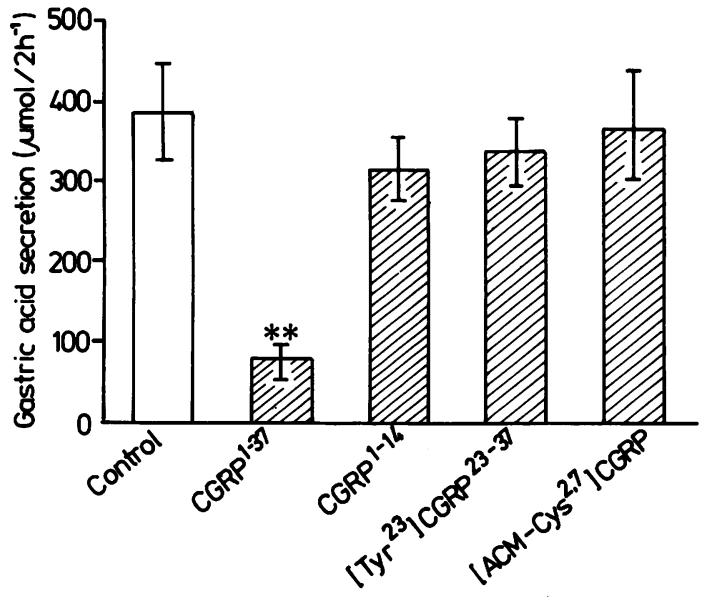

Fig. 2 Effects of CGRP $P^{l-37}$ (complete peptide molecule), $C G R P^{1-14}$ (N-terminus), [Tyr $\left.{ }^{23}\right] C G R P^{23-37}$ (C-terminal fragment), and [ACM-cys $\left.{ }^{2,7}\right] C G R P$ ([acetamidomethylcys $^{2,7}$ JCGRP), the linear cysteine-protected molecule, on mean $\pm S E$ gastric acid secretion in awake freely moving rats $(n=6)$. The peptides $(1 \mathrm{nmol})$ or control were injected intravenously as a bolus before pylorus ligation. Two hours later the animals were decapitated and gastric acid secretion determined. ${ }^{* *}, p<0.01$ compared with control.

For comparison, calcitonin gene related peptide decreased the two hour total acid outputs in response to pentagastrin, histamine, and bethanecol by 53,44 , and $54 \%$, respectively.

The inhibiting effect of calcitonin gene related peptide $(2.2 \mathrm{nmol})$ on gastric secretion in vagotomised rats is depicted in Figure 4. Truncal vagotomy alone decreased the two hour total acid output in response to pentagastrin by $45 \%$ (Figs. 4 , 5). Similarly, calcitonin gene related peptide decreased the two hour total acid output by $52 \%$ in sham-operated and by $55 \%$ in vagotomised animals (Figs. 4, 5). The acid secretory responses after calcitonin gene related peptide in the sham-operated or vagotomised rats were not significantly different from one another or when compared with the vagotomised control group at any given time point (Fig. 4).

Figure 5 shows the effect of calcitonin gene related peptide $(2.2 \mathrm{nmol})$ on pentagastrinstimulated two hour total acid output in vagotomised rats and in animals pretreated with atropine. Compared with truncal vagotomy in the control group, pretreatment of the animals with atropine resulted in similar gastric acid inhibition: $45 \%$ vs $53 \%$, respectively. Calcitonin gene related peptide did not decrease the total acid output in vagotomised or atropinised animals when compared
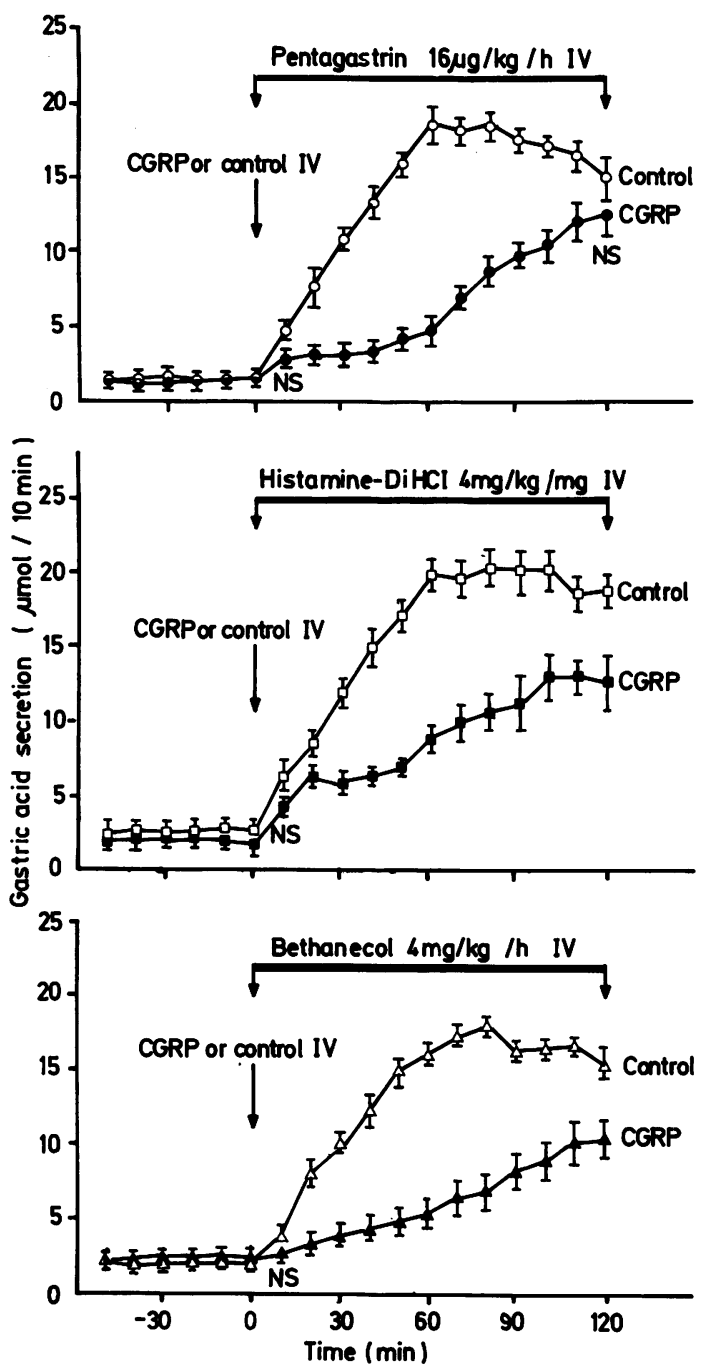

Fig. 3 Effect of CGRP $(2 \cdot 2 \mathrm{nmol})$ on mean $\pm S E$ gastric acid secretion stimulated by pentagastrin (upper panel), histamine (middle panel), or bethanecol (lower panel) $(n=6)$. Calcitonin gene related peptide decreased gastric secretion significantly $(p<0.01)$ compared with the control groups in response to each of the three stimuli. ns indicates that inhibition was not significant at the indicated time points.

with the respective controls (Fig. 5).

\section{Discussion}

Over the past years, a number of gastrointestinal peptides have been shown to inhibit gastric acid secretion including secretin, ${ }^{9}$ cholecystokinin, ${ }^{10}$ 
Fig. 4 Effect of calcitonin gene related peptide $(2 \cdot 2 \mathrm{nmol})$ on pentagastrin-stimulated gastric acid secretion (mean $\pm S E$ ) in vagotomised animals $(n=8)$. No significant differences of acid secretion were observed between calcitonin gene related peptide and control in vagotomised (Vag-x) rats or sham-operated (sham) rats treated with calcitonin gene related peptide.

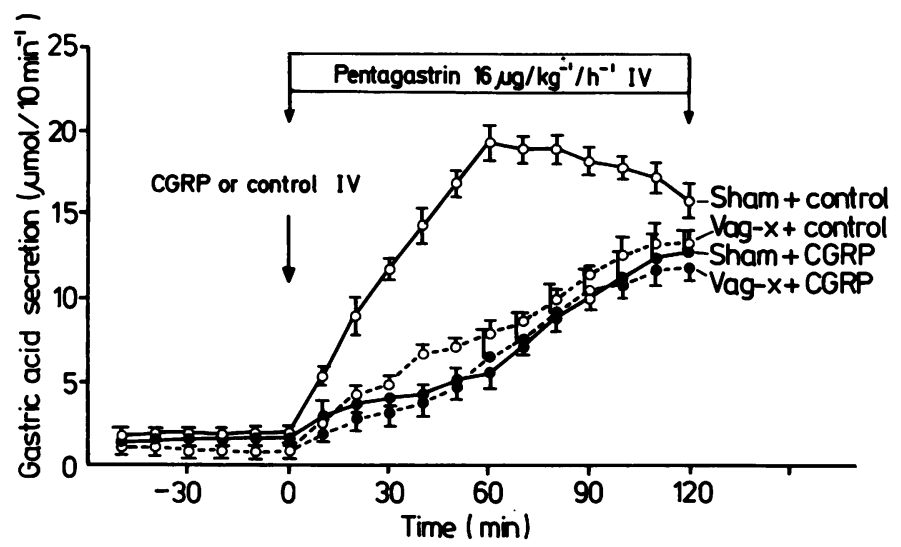

gastric inhibitory polypeptide ${ }^{11}$ vasoactive intestinal polypeptide ${ }^{12}$ glucagon, ${ }^{13}$ neurotensin, ${ }^{14}$ somatostatin, ${ }^{15}$ and thyrotropin-releasing hormone. ${ }^{16}$ The results of the present study indicate that calcitonin gene related peptide administered intravenously decreases gastric acid secretion in conscious, freely moving rats. The physiologic significance of this biological action, however, has not been unequivocally established for any of the aforementioned peptides. ${ }^{17}$ While secretin has been implicated to be a physiologic regulator of gastric

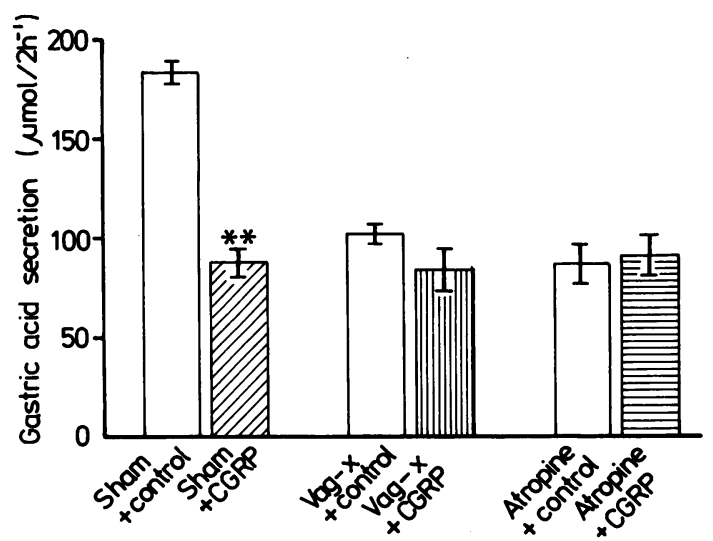

Fig. 5 Effect of calcitonin gene related peptide on two hour total acid output (mean $\pm S E$ ) in vagotomised rats and animals pretreated with atropine sulphate $(1 \mathrm{mg} / \mathrm{kg} / \mathrm{sc})$. Calcitonin gene related peptide $(2.2 \mathrm{nmol})$ or control $(\mathrm{NaCl}$; $0 \cdot 15 \mathrm{M})$ were given intravenously as a bolus injection immediately before a two hour pentagastrin $(16 \mu \mathrm{g} / \mathrm{kg} / \mathrm{h})$ infusion. ${ }^{* *}, p<0.01$ compared with sham + control $(n=6)$. Gastric acid secretion was determined as described in Fig. 4 and the two hour total acid outputs were calculated. secretion in the dog, ${ }^{9}$ a recent study by Kleibeuker et al did not indicate that the gastric inhibitory effect of secretin was of physiologic importance in man. ${ }^{18}$

Because the gastric inhibitory gut peptides have not been studied in a comparative fashion in one single species and as the half-maximal effective doses have not been reported for each of these peptides, it is difficult to evaluate their relative potency in inhibiting gastric secretion. Considering the lowest effective dose that significantly decreases gastric secretion, calcitonin gene related peptide appears to be the most potent peptide that inhibits gastric acid secretion. ${ }^{9-16}$

Calcitonin gene related peptide has been identified immunohistochemically throughout the gastrointestinal tract (personal communication). Furthermore, calcitonin gene related peptide-like immunoreactivity has also been found throughout the gut of the rat, predominantly in the stomach and duodenum (manuscript in preparation). Both the potency of calcitonin gene related peptide in inhibiting acid secretion as well as its distribution in those areas of the gastrointestinal tract that control gastric functions imply that calcitonin gene related peptide may be a new candidate enterogastrone. ${ }^{19}$

Neither the $\mathrm{N}$-terminal residue, CGRP ${ }^{1-14}$, nor the C-terminal fragment, $\left[\mathrm{Tyr}^{23}\right] \mathrm{CGRP}^{23-37}$, altered gastric acid secretion suggesting that the whole peptide molecule may be required for biological activity. Although less likely, we cannot exclude that either fragment was too short in length in order to precisely determine the region specific structureactivity relationship. Also, the biologically active part of calcitonin gene related peptide may be located within the middle portion of the peptide. As the linear cysteine-protected molecule, [ACMcys $^{2,7}$ ] calcitonin gene related peptide, did not affect the secretory response, it appears that the 
disulphide bridge of the $\mathrm{N}$-terminus is necessary for the gastric inhibitory action of calcitonin gene related peptide. Similarly, the entire 32 -amino acid chain of calcitonin including the disulphide bridge appears to be required for lowering serum calcium. ${ }^{20}$ While the primary structures of calcitonin gene related peptide and calcitonin are distinct, ${ }^{1}$ it is of interest that both peptides inhibit gastric acid secretion $^{21}$ but only calcitonin lowers serum calcium and phosphorus (unpublished observations).

A bolus injection of calcitonin gene related peptide inhibited gastric acid secretion in response to a maximal dose of either pentagastrin, histamine, or bethanecol. Secretin and neurotensin also inhibited pentagastrin, but not histamine stimulated gastric acid secretion. ${ }^{12} 22$ Gastric inhibitory peptide decreased acid secretion stimulated by pentagastrin, histamine, and insulin. ${ }^{11}$ While gastric inhibitory peptide was more potent in inhibiting pentagastrin than histamine stimulated acid secretion, ${ }^{11}$ calcitonin gene related peptide appears to decrease gastric acid secretion similarly in response to these two secretagogues. Calcitonin gene related peptide inhibits acid secretion stimulated by pentagastrin, histamine, and bethanecol which are thought to act through receptors on the parietal cell. ${ }^{23}$ Therefore, it is tempting to speculate that calcitonin gene related peptide might interfere with a common pathway of the acid secretory process at or near the parietal cell that is shared by those three secretagogues.

Calcitonin gene related peptide is widely distributed in nerve fibres of blood vessels and visceral organs. $^{2}$ Recently, Mason et al (personal communication) showed that calcitonin gene related peptide was released and secreted from neuronal cells ${ }^{24}$ and Sawchenko et al found that calcitonin gene related peptide was localised in cholinergic neurones in the brain (personal communication). Therefore, calcitonin gene related peptide may act as a neurotransmitter as it has already been suggested for vasoactive intestinal peptide ${ }^{25}$ and bombesin. $^{26}$

We recently reported that calcitonin gene related peptide injected either intracerebroventricularly or intravenously inhibited gastric acid secretion in freely moving rats. ${ }^{27}$ While we also show that calcitonin gene related peptide given intracerebroventricularly did act within the brain to decrease gastric acid secretion, ${ }^{27}$ the site of action of peripherally administered calcitonin gene related peptide is unknown. Presently we cannot exclude that calcitonin gene related peptide given intravenously may also act within the central nervous system to inhibit gastric secretion. Because calcitonin gene related peptide administered intra- cerebroventricularly increased mean arterial pressure while calcitonin gene related peptide given intravenously decreased mean arterial pressure ${ }^{3}$ it is possible that calcitonin gene related peptide may act at both a central and a peripheral site. Further studies are needed using isolated organ and cell systems to determine precisely a peripheral site of action of calcitonin gene related peptide.

A submaximal dose of calcitonin gene related peptide $(2 \cdot 2 \mathrm{nmol})$ inhibited pentagastrin-stimulated gastric acid secretion by about $50 \%$ and similarly compared with truncal vagotomy. As calcitonin gene related peptide did not exhibit any inhibitory effect in the vagotomised animals, inhibition of gastric acid secretion may be mediated by a vagally dependent pathway. Furthermore, calcitonin gene related peptide $(2 \cdot 2 \mathrm{nmol})$ did not inhibit pentagastrin stimulated acid secretion in animals pretreated with atropine suggesting that calcitonin gene related peptide acts through a cholinergic sensitive pathway.

Sham feeding inhibited pentagastrin stimulated acid secretion from Heidenhain pouches ${ }^{28}$ and truncal vagotomy increased the maximal acid response to gastrin. ${ }^{29}$ These findings led to the interpretation that basal vagal activity releases a substance that inhibits gastric secretion. The hypothetical substance has been referred to as vagogastrone. ${ }^{30}$ It is possible, although speculative, that calcitonin gene related peptide release may be under vagal control.

In summary, calcitonin gene related peptide, a novel neuropeptide, administered intravenously is a potent inhibitor of basal as well as pentagastrin, histamine, and bethanol stimulated gastric acid secretion in the rat. The complete 37-residue chain including the $\mathrm{N}$-terminal disulphide bridge appears to be required for biological activity. Inhibition of gastric acid secretion by calcitonin gene related peptide may be mediated by a vagal, cholinergic pathway.

Research supported by NIH Grant AM 26741 and the Deutsche Forschungsgemeinschaft, Grant Le 470/1-3. Research conducted in part by the Clayton Foundation for Research-California Division. M R Brown is a Clayton Foundation Investigator. The authors thank Drs Charles F Code and Jon I Isenberg of their critical comments, Robert Galyean, and Ron Kaiser for technical assistance, and Susan Logan for manuscript preparation.

\section{References}

1 Amara SG, Jonas V, Rosenfeld MG, Ong SE, Evans 
RM. Alternative RNA processing in calcitonin gene expression generates mRVAs encoding different polypeptide products. Nature 1982; 298: 240-4.

2 Rosenfeld MG, Mermod J-J, Amara SG et al. Production of a novel neuropeptide encoded by the calcitonin gene via tissue-specific RNA processing. Nature 1983; 304: 129-35.

3 Fisher LA, Kikkawa DO, Rivier JE et al. Stimulation of noradrenergic sympathetic outflow by calcitonin gene-related peptide. Nature 1983; 305: 534-6.

4 Shay $H$, Sun DCH, Gruenstein M. A quantitative method for measuring spontaneous gastric secretion in the rat. Gastroenterology 1954; 26: 906-13.

5 Isenberg JI. Gastric secretory testing. In: Sleisenger MH, Fordtran SJ, eds. Gastrointestinal disease: pathophysiology, diagnosis, management. Philadelphia: W B Saunders, 1978: 714-32.

6 Goto Y, Debas HT. GABA-mimetic effect on gastric acid secretion: possible significance in central mechanisms. Dig Dis Sci 1983; 28: 56-60.

7 Shay H, Komarov SA, Gruenstein M. Effects of vagotomy in the rat. Arch Surg 1949; 59: 210-6.

8 Rivier J, Kaiser R, Galyean R. Solid phase synthesis of somatostatin and glucagon selective analogs. Biopolymers 1978, 17: 1927-38.

9 Chey WY, Kim MS, Lee KY, Chang TM. Secretin is an enterogastrone in the dog. Am J Physiol 1981; 240: G239-44.

10 Johnson LR, Grossman MI. Analysis of inhibition of acid secretion by cholecystokinin in dogs. Am J Physiol 1970; 218: 550-4.

11 Pederson RA, Brown JC. Inhibition of histamine-, pentagastrin-, and insulin-stimulated canine gastric secretion by pure gastric inhibitory polypeptide. Gastroenterology 1972; 62: 393-400.

12 Kouturek SJ, Dembinski A, Thor P, Krol R. Comparison of vasoactive intestinal peptide (VIP) and secretin in gastric secretion and mucosal blood flow. Pflugers Arch 1976; 361: 175-81.

13 Christiansen J, Holst JJ, Kalaja E. Inhibition of gastric acid secretion in man by exogerious and endogenous pancreatic glucagon. Gastroenterology 1976; 70: 68892.

14 Blackburn AM, Bloom SR, Long RG et al. Effect of neurotensin on gastric function in man. Lancet 1980; 1 : 987-9.

15 Creutzfeld W, Arnold R. Somatostatin and the stomach: exocrine and endocrine aspects. Metabolism 1978; 27: 1309-15.

16 Dolva LO, Hanssen KF, Berstad A, Frey HMM. Thyrotropin-releasing hormone inhibits the pentagastrin stimulated gastric secretion in man. A dose response study. Clin Endocrinol 1979; 10: 281-6.

17 Walsh JH. Gastrointestinal hormones and peptides. In: Johnson LR, ed. Physiology of the gastrointestinal tract. New York: Raven Press, 1981: 59-144.

18 Kleibeuker JH, Eysselein VE, Maxwell VE, Walsh JH. Role of endogenous secretin in acid-induced inhibition of human gastric function. J Clin Invest 1984; 73: 526-32.

19 Gregory RA. Enterogastrone - a reappraisal of the problem. Shnitka TK, Gilbert JAL, Harrison RC, eds. Gastric secretion. New York: Pergamon Press, 1967: 469-77.

20 Aurbach GD, Marks SJ, Spiegel AM. Parathyroid hormone, calcitonin, and the calciferols. In: Williams RH, ed. Textbook of endocrinology. Philadelphia: W B Saunders, 1981: 922-1031.

21 Bieberdorf FA, Gray TK, Walsh JH, Fordtran JS. Effect of calcitonin on meal-stimulated gastric acid secretion and serum gastrin concentration. Gastroenterology 1974; 66: 343-6.

22 Andersson S, Chang D, Folkers K, Rosell S. Inhibition of gastric acid secretion in dogs by neurotensin. Life Sci 1976; 19: 367-70.

23 Soll $\mathrm{AH}$. The actions of secretagogues on oxygen uptake by isolated mammalian parietal cells. J Clin Invest 1978; 61: 370-80.

24 Mason RT, Peterfreund RA, Sawchenko PE, Corrigan AZ, Rivier JE, Vale WW. Release of the predicted calcitonin gene-related peptide from cultured rat trigeminal ganglion cells. Nature 1984 ; 308: 653-5.

25 Lundberg JM, Anggard A, Fahrenkrug J, Hokfelt T, Mutt V. Vasoactive intestinal polypeptide in cholinergic neurons of exocrine glands: functional significance of coexisting transmitters for vasodilation and secretion. Proc Natl Acad Sci USA 1980; 77: 1651-5.

26 DuVal JW, Saffouri B, Weir GC, Walsh JH, Arimura A, Makhlouf GM. Stimulation of gastrin and somatostatin secretion from the isolated rat stomach by bombesin. Am J Physiol 1981; 241: G242-7.

27 Lenz HJ, Mortrud MT, Rivier J, Vale WW, Brown MR, Calcitonin gene-related peptide inhibits gastric acid secretion. Clin Res 1984; 32: 26 A.

28 Sjodin L. Inhibition of gastrin-stimulated canine acid secretion by sham-feeding. Scand J Gastroenterol 1975; 10: $73-80$.

29 Emas S, Grossman MI. Response of heidenhain pouch to histamine, gastrin, and feeding before and after truncal vagotomy in dogs. Scand J Gastroenterol 1969; 4: 497-503.

30 Grossman MI. Candidate hormones of the gut. Gastroenterology 1974; 67: 730-57. 